\title{
Dimensionless analysis for modelling surface finish in conventional investment casting
}

\author{
Rupinder Singh ${ }^{1^{*}}$ and Sunpreet Singh ${ }^{2}$ \\ ${ }^{1}$ Production Engineering Department, GNDEC, Ludhiana, India 141006 \\ ${ }^{2}$ Production Engineering Department, GNDEC, Ludhiana, India 141006 \\ *Corresponding author E-mail: rupindersingh78@yahoo.com
}

\begin{abstract}
High level surface finish (SF) achievement is one of the major advantages of conventional investment casting process. Not much work hitherto has been reported for modeling the SF in conventional investment casting of industrial components. In the present study application of dimensionless analysis, has been made for developing a mathematical model for SF. Three input process parameters (namely: molten metal pouring temperature (PT), slurry layer's combination (LC) and volume/surface-area (V/A) ratio of cast components) were judicially selected to give SF as output. This study provide main effects of these input parameters on $S F$ and shed light on the SF mechanism in conventional investment casting. The comparison of mathematical model with experimental results has been made for validation of model.
\end{abstract}

Keywords: cconventional investment casting, surface finish, dimensionless analysis, volume/surface-area ratio of components, pouring temperature.

$\begin{array}{ll}\text { NOMENCLATURE } \\ \text { SF } & \text { Surface finish } \\ \text { CIC } & \text { Conventional investment casting } \\ \text { PT } & \text { Pouring temperature } \\ \text { LC } & \text { Layer combination } \\ \text { V/A } & \text { Volume/surface area } \\ \text { OA } & \text { Orthogonal array } \\ \text { Al } & \text { Aluminium } \\ \text { SS } & \text { Stainless steel } \\ \text { MS } & \text { Mild steel } \\ \text { Ra } & \text { Surface roughness } \\ \text { S/N } & \text { Signal/noise } \\ \text { S.N. } & \text { Serial no. } \\ \text { T } & \text { Temperature } \\ \text { M } & \text { Mass } \\ \text { L } & \text { Length }\end{array}$

\section{GREEK SYMBOLS}

Mathematical constant equal to a circle's $\Pi$ circumference divided by its diameter

$\Theta$ Temmperature

A Alpha

B Beta

Г Gama

\section{INTRODUCTION}

Conventional investment casting (CIC) is one of the oldest manufacturing processes ${ }^{1-2}$. The process is also known as lost wax process ${ }^{3}$. The previous studies have highlighted that CIC results into exact shape of cavity geometry with high level of $\mathrm{SF}^{2-5}$. An exact/ uniform SF profile, (which generally takes into account the various shrinkages involved, while solidification) in CIC process, is therefore, important to improve the quality of net shaped product ${ }^{6-8}$. In this sense, an accurate modelling of SF as outcome of CIC process is very helpful for controlling input process parameters. The CIC process has been in practice for some 5000 years, mainly for the production of ornamental objects, statues and jewellery. It is considered the most ancient of metal casting $\operatorname{arts}^{5-13}$. Technological advances have also made it the most modern and versatile of all metal casting processes. CIC is originally used to cast sculptures and other "works of art", it is now used to cast some of the most complex castings for some of the most critical applications ${ }^{9-13}$. Some researchers have highlighted typical applications of CIC process like: development of hollow turbine blade ${ }^{12}$, biomedical implants ${ }^{3}$ etc. Also some studies have been reported for CIC moulds with different numbers of shell layers and pre-heating temperatures which results into different properties of casting produced ${ }^{14}$. The literature review reveals that lot of work has been reported on optimization of CIC process ${ }^{9-12}$. Various process parameters (like: wax properties, number of slurry layers, size of component and mould thermal conductivity etc.) for the sound casting produced by CIC process has been reported ${ }^{13-14}$. But hitherto very less has been reported for modelling the SF (for tailor made properties) in CIC of industrial components. So, the present investigation has been focused to develop mathematical model (micro model) for SF in CIC.

For SF in CIC of commercially used metals and alloys (like: Al, M.S and S.S) a macro modelling approach has been already applied successfully ${ }^{13}$. This model was based upon Taguchi design technique. In previously reported study, effects of three input process parameters (namely: V/A ratio of cast components, LC and PT) on SF were investigated as a macro model. It should be noted that micro-modelling is based on an in-depth understanding of the system. It begins by developing a mathematical model of the system, which, in this 
case, is SF of CIC. When systems are complex, as in this case study, one must make assumption that simplify the operation, as well as put forth considerable effort to develop the model. Furthermore, the more simplifying we do, the less realistic the model will be, and, hence, the less adequate it will be for precise optimization. But once an adequate model is constructed, a number of wellknown optimization methods, can be used to find the best system configuration. For developing a mathematical model in the case under study, initially a macro-model based upon concept of Taguchi design has been made and output of this Taguchi based model has been used for developing a micro-model. In macro-modelling, we bypass the step of building a mathematical model of the system. The concern is primarily with obtaining the optimum system configuration, not with obtaining a detailed understanding of the system itself ${ }^{15-16}$.

Table 1 and 2 respectively shows list of input and output parameters used in present study and chemical composition of various inputs (metals and alloys) used in CIC.

Table 1. List of input and output parameters.

\begin{tabular}{|c|c|}
\hline Input parameters & Output parameter \\
\hline $\begin{array}{l}\text { Three levels of component } \\
\text { V/A ratio }(2.74,3.78, \\
4.09 \mathrm{~mm}) \\
\text { Three levels of } \mathrm{LC} \\
\text { 2. } \\
(1+1+2+4,1+1+3+3 \text { and } \\
1+1+4+2) \\
\text { 3. Three levels of molten } \\
\text { metal PT } \\
\left(600^{\circ} \mathrm{C}, 1550^{\circ} \mathrm{C}, 1600^{\circ} \mathrm{C}\right)\end{array}$ & $\mathrm{SF}$ \\
\hline
\end{tabular}

Table 2. Chemical compositions of various inputs to

\begin{tabular}{|c|c|}
\hline \multicolumn{2}{|r|}{ CIC process. } \\
\hline S. No. & Chemical Composition \\
\hline $\begin{array}{l}\text { Al (Aluminium } \\
\text { LM6) }\end{array}$ & $\begin{array}{c}0.1 \% \mathrm{Cu}, 0.10 \% \mathrm{Mg}, 10.0-13.0 \% \\
\mathrm{Si}, 0.6 \% \mathrm{Fe}, 0.5 \% \mathrm{Mn}, 0.1 \% \mathrm{Ni} \\
0.1 \% \mathrm{Zn}, 0.1 \% \mathrm{~Pb}, 0.05 \% \mathrm{Sn}, 0.2 \% \\
\mathrm{Ti} \text {, remainder } \mathrm{Al}\end{array}$ \\
\hline $\begin{array}{l}\text { S.S (Stainless } \\
\text { Steel 202) }\end{array}$ & $\begin{array}{c}0.12 \% \mathrm{C}, 5.5 / 7.5 \% \mathrm{Mn}, 0.9 \% \mathrm{Si} \\
16 / 18 \% \mathrm{Cr}, 0.5 / 4.0 \% \mathrm{Ni}, 0.2 \% \mathrm{Mo} \\
0.06 \% \mathrm{P}, 0.25 \% \mathrm{~N}\end{array}$ \\
\hline $\begin{array}{l}\text { M.S (Mild } \\
\text { Steel EN8) }\end{array}$ & $\begin{array}{c}0.35 / 0.45 \% \mathrm{C}, 0.6 \% \mathrm{Mn} \\
0.05 / 0.35 \% \mathrm{Si}, 0.06 \% \mathrm{P}, 0.06 \% \mathrm{~S}\end{array}$ \\
\hline Pattern Wax & $\begin{array}{c}0.50 \% \text { Paraffin, } 0.4 \% \\
\text { Microcrystalline wax, } 0.35 \% \\
\text { Montan, } 0.13 \% \text { Polymers and } \\
\text { Fillers } \\
\end{array}$ \\
\hline Slurry & $\begin{array}{c}0.70 \% \text { Zircone Flour, } 0.25 \% \\
\text { Colloidal Silica, } 0.45 \% \text { Distilled } \\
\text { Water, } 0.05 \% \text { Ethanol }\end{array}$ \\
\hline
\end{tabular}

The levels of molten metal PT (as: $600^{\circ} \mathrm{C}$, $1550^{\circ} \mathrm{C}, 1600^{\circ} \mathrm{C}$ ), component V/A ratio (as: 2.74 , $3.78,4.09 \mathrm{~mm}$ ) were judicially selected (while pilot experimentation) for CIC of ball valve's spherical discs of (Al, M.S and S.S) of three different commercially used sizes (corresponding to diameter: 2", 3" and 4") based upon field application (see Figure 1 and Figure 2). It should be noted that normally spherical disc of Al, M.S and S.S are used in ball valve. $L C$ of $1+1+2+4$ represents: one layer of zircon paint (one, primary $/ 1^{\circ}$ layer), one layer of silica slurry of $80-100$ mesh (one, secondary/2 ${ }^{\circ}$ layer), two layers of silica slurry of 50-80 mesh (two, tertiary $/ 3^{\circ}$ layers), and four layers of silica slurry of 30-50 mesh (four, quarterly $/ 4^{\circ}$ layers).
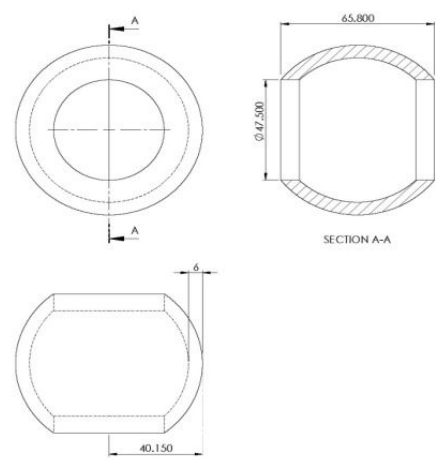

(a)

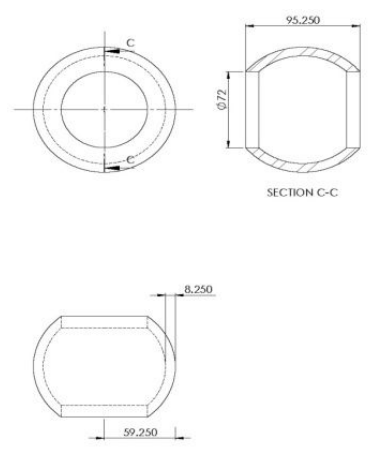

(b)

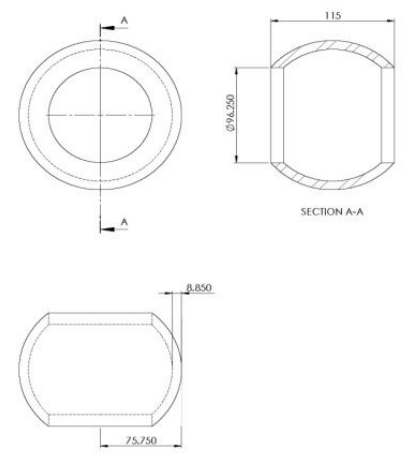

(c)

Figure 1. 2-D view of spherical disc (a) 2", (b) 3" and (c) 4". 


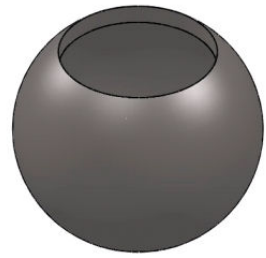

Figure 2. 3-D view of spherical disc.

Similarly $1+1+3+3$ represents: one layer of zircon paint (one, $1^{\circ}$ layer), one layer of silica slurry of 80 100 mesh (one, $2^{\circ}$ layer), three layers of silica slurry of 50-80 mesh (three, $3^{\circ}$ layers), and three layers of silica slurry of 30-50 mesh (three, $4^{\circ}$ layers) and $(1+1+4+2)$ represents: one layer of zircon paint (one, $1^{\circ}$ layer), one layer of silica slurry of 80-100 mesh (one, $2^{\circ}$ layer), four layers of silica slurry of 50-80 mesh (four, $3^{\circ}$ layers), and two layers of silica slurry of 30-50 mesh (two, $4^{\circ}$ layers). The total number of $1^{\circ}+2^{\circ}+3^{\circ}+4^{\circ}$ layers has been kept fixed equal to 8 based upon pilot experimentation, as because during the process of shell formation, it was observed from pilot experimentation that the shell with less than 8 layers cracks while de-waxing. Now by keeping total number of layers as 8 fixed, three variations has been made in $3^{\circ}$ and $4^{\circ}$ layers as $1+1+2+4,1+1+3+3$, $1+1+4+2$.The drying conditions were $27^{\circ} \mathrm{C}$ temperature and humidity $60 \%$. Table 3 shows control log of experimentation.

Table 3. Control log of experimentation.

\begin{tabular}{|c|c|c|c|}
\hline S.N. & $\begin{array}{c}\text { V/A } \\
\text { ratio }\end{array}$ & LC & $\begin{array}{c}\text { Type of Metal/ } \\
\text { PT, }{ }^{\circ} \mathrm{C}\end{array}$ \\
\hline 1 & 2.74 & $1+1+3+3$ & $\mathrm{Al}\left(600^{\circ} \mathrm{C}\right)$ \\
\hline 2 & 2.74 & $1+1+2+4$ & $\mathrm{~S} . \mathrm{S}\left(1550^{\circ} \mathrm{C}\right)$ \\
\hline 3 & 2.74 & $1+1+4+2$ & $\mathrm{M} . \mathrm{S}\left(1600^{\circ} \mathrm{C}\right)$ \\
\hline 4 & 3.78 & $1+1+3+3$ & $\mathrm{~S} . \mathrm{S}\left(1550^{\circ} \mathrm{C}\right)$ \\
\hline 5 & 3.78 & $1+1+2+4$ & $\mathrm{M} . \mathrm{S}\left(1600^{\circ} \mathrm{C}\right)$ \\
\hline 6 & 3.78 & $1+1+4+2$ & $\mathrm{Al}\left(600^{\circ} \mathrm{C}\right)$ \\
\hline 7 & 4.09 & $1+1+3+3$ & $\mathrm{M} . \mathrm{S}\left(1600^{\circ} \mathrm{C}\right)$ \\
\hline 8 & 4.09 & $1+1+2+4$ & $\mathrm{Al}(600)$ \\
\hline 9 & 4.09 & $1+1+4+2$ & $\mathrm{~S} . \mathrm{S}\left(1550^{\circ} \mathrm{C}\right)$ \\
\hline
\end{tabular}

\section{DESCRIPTION OF THE CIC PROCESS}

The CIC process is a 12 step process, which involves: injecting wax into dies, ejection of patterns, pattern assembly or tree making, slurry coating, stucco coating, mould completion, pattern melt-out or de-waxing, mould baking, pouring, shakeout, cutting of rise and at last the final product produced ${ }^{12-14}$.
Figure 3 shows 3D view of wax trees prepared and pouring of molten motel in investment shells. The major CIC process variables affecting SF are shown as fishbone diagram (see Figure 4).

The study presented in this paper is extension of previously published macro model based on Taguchi robust design ${ }^{13}$. Now based upon macro model, dimensionless analysis has been used to study the relationships between $\mathrm{SF}$ and input process parameters as extension of previously published work $^{13,15}$.

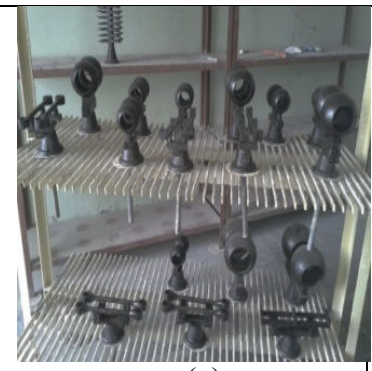

(a)

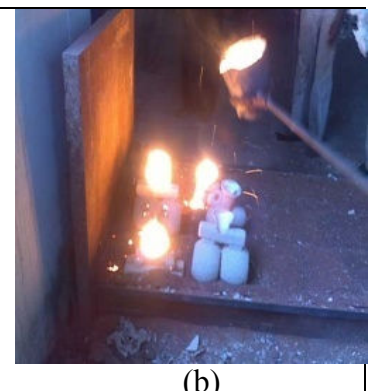

(b)
Figure 3. (a) Wax trees (b)pouring of molten metal

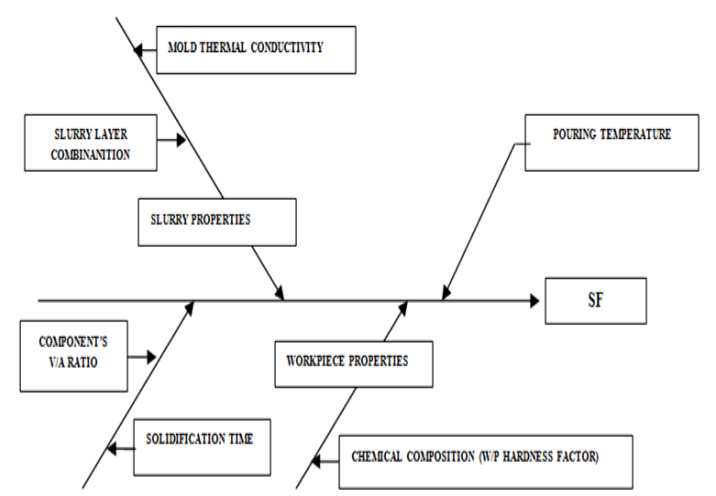

Figure 4. Fish-bone diagram for SF in CIC.

\section{MICRO MODELING Of SF}

As per macro model PT, LC and V/A ratio were significantly affecting SF in CIC. Table 4, 5 and 6 respectively shows $\mathrm{S} / \mathrm{N}$ ratio calculations, percentage contribution of input parameters (PT, LC and V/A ratio) and geometric model for SF.

As per approach of dimensionless analysis, in a physical problem including " $n$ " quantities in which there are " $m$ " dimensions, the quantities can be arranged in to " $n-m$ " independent dimensionless parameters $^{16-18}$. Based upon Figure 3, SF (symbolic representation as ' $\mathrm{R}_{\mathrm{a}}$ ') depends upon input parameters (namely: V/A ratio, LC, PT, type of metal (W/P hardness factor), mold thermal conductivity and solidification time), therefore by selecting basic dimensions: 
- $\quad \mathrm{T}$ (time),

- $\theta$ (temperature),

- $\quad \mathrm{M}$ (mass) and

- L (length).

The dimensions of foregoing quantities (different parameters) are shown in Table 7.

Table 4. S/N ratio calculations for SF.

\begin{tabular}{|c|c|c|c|c|c|}
\hline E1 & E2 & E3 & $\begin{array}{c}\text { Sum of } \\
\text { square }\end{array}$ & $\begin{array}{c}\text { S/N } \\
\text { ratio }\end{array}$ & Average \\
\hline 1.62 & 1.65 & 1.58 & 2.614433 & $\begin{array}{c}- \\
4.1737\end{array}$ & 1.6166 \\
\hline 2.42 & 2.5 & 2.4 & 5.955467 & $\begin{array}{c}- \\
7.7491\end{array}$ & 2.4444 \\
\hline 2.03 & 2.09 & 2.12 & 4.3278 & $\begin{array}{c}- \\
6.3626\end{array}$ & 2.088 \\
\hline 2.03 & 1.95 & 1.99 & 3.961167 & - \\
5.9782 & 1.999 \\
\hline 2.7 & 2.74 & 2.69 & 7.344567 & $\begin{array}{c}- \\
8.6596\end{array}$ & 2.710 \\
\hline 1.55 & 1.57 & 1.59 & 2.465167 & $\begin{array}{c}- \\
3.9184\end{array}$ & 1.570 \\
\hline 2.42 & 2.5 & 2.4 & 5.955467 & - & 2.444 \\
& & & & 7.7491 & \\
\hline 2.3 & 2.23 & 2.27 & 5.1386 & - & 2.266 \\
\hline 2.32 & 2.35 & 2.38 & 5.5231 & $\begin{array}{c}- \\
7.4218\end{array}$ & 2.350 \\
\hline
\end{tabular}

Note: E1, E2 and E3 represents the three readings obtained after repeating the experimental setup as described in Table 3.

Table 5. Percentage contribution for SF.

\begin{tabular}{|c|c|c|}
\hline Parameters & Sum of square & $\begin{array}{c}\text { Percentage } \\
\text { contribution }\end{array}$ \\
\hline V/A & 0.203193 & $15.56 \%$ \\
\hline LC & 1.5739795 & $34.06 \%$ \\
\hline PT & 360.75569 & $49.66 \%$ \\
\hline Error & 0.203193 & $0.70 \%$ \\
\hline
\end{tabular}

Table 6. Geometric model for SF.

\begin{tabular}{|c|c|}
\hline \multicolumn{2}{|c|}{ Optimized conditions for SF } \\
\hline V/A & $2.74 \mathrm{~mm}$ \\
\hline LC & $1+1+4+2$ \\
\hline PT & $600^{\circ} \mathrm{C}$ \\
\hline
\end{tabular}

Now based upon Table 7, SF can be written as Eq. 1:

$$
\mathrm{R}_{\mathrm{a}}=\mathrm{f}\left(\mathrm{N}_{1}, \mathrm{R}, \mathrm{F}, \theta, \mathrm{K}, \mathrm{t}\right)
$$

Presently, " $n$ " is 7 and " $m$ " is 4 . So, we can have " $\mathrm{n}-\mathrm{m}=3$ ". Hence $\pi_{1}, \pi_{2}$ and $\pi_{3}$ three dimensionless groups ${ }^{15}$.

Taking $\mathrm{R}_{\mathrm{a}}, \mathrm{R}$ and $\theta$ as the quantities which directly go in $\pi_{1}, \pi_{2}$ and $\pi_{3}$ respectively, it can be written as ${ }^{15}$ :

$$
\begin{aligned}
& \pi_{1}= \mathrm{R}_{\mathrm{a}} \cdot(\mathrm{K})^{\alpha 1} \cdot(\mathrm{F})^{\beta 1} \cdot\left(\mathrm{N}_{1}\right)^{\gamma 1} \cdot(\mathrm{t})^{\delta 1} \\
& \pi_{2}=\mathrm{R}(\mathrm{K})^{\alpha 2} \cdot(\mathrm{F})^{\beta 2} \cdot\left(\mathrm{N}_{1}\right)^{\gamma 2} \cdot(\mathrm{t})^{\delta 2} \\
& \pi_{3}=\theta \cdot(\mathrm{K})^{\alpha 3} \cdot(\mathrm{F})^{\beta 3} \cdot\left(\mathrm{N}_{1}\right)^{\gamma 3} \cdot(\mathrm{t})^{\delta 3}
\end{aligned}
$$

Table 7. Conversion of different parameters into equivalent basic dimensions.

\begin{tabular}{|c|c|c|c|c|}
\hline $\begin{array}{c}\text { S. } \\
\text { No. }\end{array}$ & 1 & 2 & 3 & \multicolumn{2}{|c|}{4} \\
\hline 1 & $\mathrm{SF}$ & $\mathrm{R}_{\mathrm{a}}$ & $\mu \mathrm{m}$ & $\mathrm{L}^{1}$ \\
\hline 2 & $\mathrm{LC}$ & $\mathrm{N}_{1}$ & $\mathrm{~mm}$ & $\mathrm{~L}^{1}$ \\
\hline 3 & $\begin{array}{c}\text { Compo } \\
\text { nent's } \\
\text { V/A } \\
\text { ratio }\end{array}$ & $\mathrm{R}$ & $\mathrm{mm}$ & $\mathrm{L}^{1}$ \\
\hline 4 & $\begin{array}{c}\text { Type of } \\
\text { metal/ } \\
\text { W/P } \\
\text { hardnes } \\
\text { s factor }\end{array}$ & $\mathrm{F}$ & $\begin{array}{c}\text { kgf/mm } \\
\text { (Vickers } \\
\text { hardness) }\end{array}$ & $\mathrm{M} \mathrm{L}^{-1} \mathrm{~T}^{-2}$ \\
\hline 5 & $\begin{array}{c}\text { Molten } \\
\text { metal } \\
\text { pouring } \\
\text { tempera } \\
\text { ture }\end{array}$ & $\theta$ & ${ }^{\circ} \mathrm{C}$ & $\theta$ \\
\hline
\end{tabular}

Note: 1, 2, 3 and 4 respresents the short name, symbolic form, units and basic dimension.

Substituting the dimensions of each quantity and equating to zero, the ultimate exponent of each basic dimension has been achieved, since the " $\pi_{\mathrm{i}} \mathrm{s}$ " are dimensionless groups ${ }^{15-16}$.

Thus $\alpha \mathrm{i}, \beta \mathrm{i}, \gamma \mathrm{i}, \delta \mathrm{i}$,(where $\mathrm{i}=1,2,3 \ldots$ ) can be solved.

Solving for $\pi_{1}$ :

$\pi_{1}=(\mathrm{L}) .\left(\mathrm{M} \mathrm{L} \mathrm{T}^{-3} \theta^{-1}\right)^{\alpha 1} \cdot\left(\mathrm{M} \mathrm{L}^{-1} \mathrm{~T}^{-2}\right)^{\beta 1} \cdot(\mathrm{L})^{\gamma 1} \cdot(\mathrm{T})^{\delta 1}$

Here,

M: $\quad \alpha_{1}+\beta_{1}=0$

L: $\quad 1+\alpha_{1}-\beta_{1}+\gamma_{1}=0$

T: $\quad-3 \alpha_{1}-2 \beta_{1}+\delta_{1}=0$

$\theta: \quad \alpha_{1}=0$

We get:

Thus

$$
\alpha_{1}=0, \quad \beta_{1}=0, \quad \gamma_{1}=-1, \quad \delta_{1}=0
$$

$$
\pi_{1}=\mathrm{R}_{\mathrm{a}} / \mathrm{N}_{1}
$$

Similarly we get:

$\pi_{2}=(\mathrm{L}) \cdot\left(\mathrm{M} \mathrm{L} \mathrm{T}^{-3} \theta^{-1}\right)^{\alpha 2} \cdot\left(\mathrm{M} \mathrm{L}^{-1} \mathrm{~T}^{-2}\right)^{\beta 2} \cdot(\mathrm{L})^{\gamma 2} \cdot(\mathrm{T})^{\delta 2}$

Here, 


$$
\begin{aligned}
& \text { M: } \quad \alpha_{2}+\beta_{2}=0 \\
& L: \quad 1+\alpha_{2}-\beta_{2}+\gamma_{2}=0 \\
& \text { T: } \quad-3 \alpha_{2}-2 \beta_{2}+\delta_{2}=0 \\
& \theta: \quad \alpha_{2}=0 \\
& \text { We get: } \\
& \text { Thus } \\
& \alpha_{2}=0, \quad \beta_{2}=0, \quad \gamma_{2}=-1, \quad \delta_{2}=0 \\
& \pi_{2}=\mathrm{R} / \mathrm{N}_{1}
\end{aligned}
$$

Similarly:

$$
\pi_{3}=(\theta) .\left(\mathrm{M} \mathrm{L} \mathrm{T}^{-3} \theta^{-1}\right)^{\alpha 3} \cdot\left(\mathrm{M} \mathrm{L}^{-1} \mathrm{~T}^{-2}\right)^{\beta 3} \cdot(\mathrm{L})^{\gamma 3} \cdot(\mathrm{T})^{\delta 3}
$$

Here,

$$
\begin{array}{ll}
M: & \alpha_{3}+\beta_{3}=0 \\
L: & \alpha_{3}-\beta_{3}+\gamma_{3}=0 \\
T: & -3 \alpha_{3}-2 \beta_{3}+\delta_{3}=0 \\
\theta: & 1-\alpha_{3}=0
\end{array}
$$

Solving, we get:

$$
\alpha_{3}=1, \quad \beta_{3}=-1, \quad \gamma_{3}=-2, \quad \delta_{3}=1
$$

Thus

$$
\pi_{3}=\theta \cdot(\mathrm{K}) \cdot(\mathrm{F})^{-1} \cdot\left(\mathrm{N}_{1}\right)^{-2} \cdot(\mathrm{t})
$$

The ultimate relationship can be assumed to be of the form is given in Eq.11:

$$
\pi_{\mathrm{i}}=\mathrm{f}\left(\pi_{\mathrm{j}}, \pi_{\mathrm{k}}\right)
$$

Let's assume that $\mathrm{i}=1, \mathrm{j}=2, \mathrm{k}=3$ then the functional relationship is of the form:

Or

$$
\pi_{1}=\mathrm{f}\left(\pi_{2}, \pi_{3}\right)
$$

$$
\mathrm{R}_{\mathrm{a}} / \mathrm{N}_{1}=\mathrm{f}\left(\mathrm{R} / \mathrm{N}_{1}, \theta \cdot(\mathrm{K}) \cdot(\mathrm{F})^{-1} \cdot\left(\mathrm{N}_{1}\right)^{-2} \cdot(\mathrm{t})\right)
$$

It has been experimentally found that SF directly goes with $\theta^{13}$. This means metal PT significantly affects the SF. Therefore metal PT has been taken as representative for development of mathematical equation.

Thus the equation becomes:

$$
\begin{aligned}
\mathrm{R}_{\mathrm{a}}=\mathrm{f}\left\{\theta . \text { K. t. R. } 1 /\left(\mathrm{N}_{1}\right)^{2}\right\} \\
\mathrm{R}_{\mathrm{a}}=\text { C. }\left\{\theta \text {. K. t. } \mathrm{R} /\left(\mathrm{N}_{1}\right)^{2}\right\}
\end{aligned}
$$

Here ' $\mathrm{C}$ ' represents constant of proportionality.

Now by keeping $\left\{\mathrm{K} . \mathrm{t} . \mathrm{R} /\left(\mathrm{N}_{1}\right)^{2}\right\}$ fixed, experiments were performed for different values of $\theta$, to find out ' $\mathrm{R}_{\mathrm{a}}$ ' and ' $\mathrm{C}$ ' in Eq.13. The actual experimental data for metal PT have been collected and plotted in Figure 5 for finding best fitting curve.

The second degree polynomial equation comes out to be best fitted curve with coefficient of co-relation $\approx 1$. Thus equation 13 of SF for this case may be rewritten as:

$$
\begin{aligned}
& (\text { for } \mathrm{LC}=1+1+2+4) \\
& \mathrm{SF}=\left[\left(6 \times 10^{-6}\right) \theta^{2}-(0.0129) \theta+8.9893\right]\left[\text { K. t. R/ }\left(\mathrm{N}_{1}\right)^{2}\right]
\end{aligned}
$$

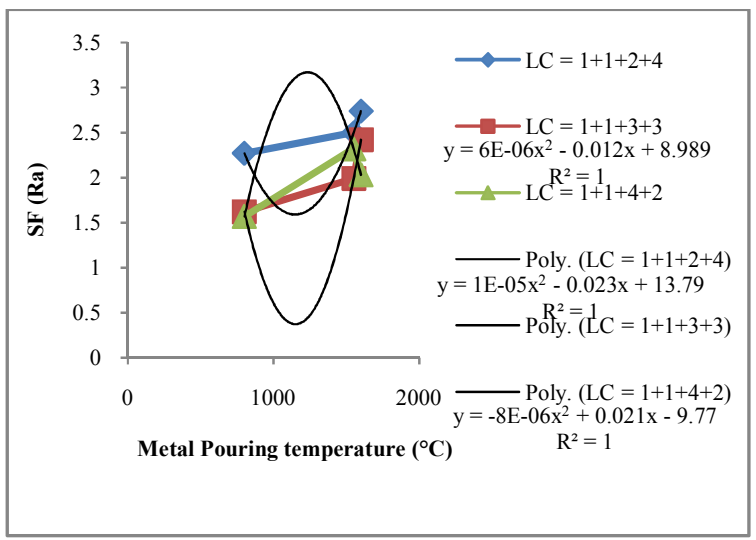

Figure 5. Variation of SF w. r. tPT

$($ For $\mathrm{LC}=1+1+3+3)$

$\mathrm{SF}=\left[\left(1 \times 10^{-5}\right) \theta^{2}-(0.0233) \theta+13.791\right]\left[\right.$ K. t. $\left.\mathrm{R} /\left(\mathrm{N}_{1}\right)^{2}\right]$

$($ For $\mathrm{LC}=1+1+4+2)$

$\mathrm{SF}=\left[\left(-9 \times 10^{-6}\right) \theta^{2}+(0.021) \theta-9.77\right]\left[\right.$ K. t. R/ $\left.\left(\mathrm{N}_{1}\right)^{2}\right]$

As this mathematical model is based upon Taguchi based model of SF, in which component's V/A ratio and LC are already optimized, therefore these parameters have not been varied while developing micro model.

The overall mechanism of SF involves: effect of PT, $\mathrm{LC}$ and V/A ratio. The best results are obtained with smallest V/A ratio (2.74), more number of $3^{\circ}$ layers $(1+2+4+2)$ and with least PT $\left(600^{\circ} \mathrm{C}\right)$. By controlling the level of other input parameters (in Eq. 14-16) one can control SF of final castings prepared by CIC (without pilot experimentation for selections of different parameters and their levels).

In casting while solidification process is going on, there are possibilities of gas holes and shrinkage cavities (having some definite dimensions). In order to check the internal defects of the castings obtained (based upon parametric settings as per Table 3 and 6), the radiography analysis was done as per ASTM E155 standard for gas holes and shrinkages (Ref. Table8). The results obtained shows that the components prepared as per Table 5, are acceptable for shrinkages and gas holes in accordance with ASTM E155 standard. 
The comparison of SF result obtained experimentally agrees very well with predictions through mathematical equations as shown in corollary below:

\section{Corollary}

The data of experiment no. 1 (Table 3 ) has been used for verification of mathematical equation. The experimental value for $\mathrm{SF}$ is $1.58-1.65 \mu \mathrm{m}$. Now by considering Eq. 15 , (for $\mathrm{LC}=1+1+3+3$ )
$\mathrm{SF}=\left[\left(1 \times 10^{-5}\right) \theta^{2}-(0.0233) \theta+13.791\right]\left[\right.$ K. t. R/ $\left.\left(\mathrm{N}_{1}\right)^{2}\right]$ Here: $\theta=600^{\circ} \mathrm{C}, \mathrm{K}=0.00338 \mathrm{~W} / \mathrm{cm}^{\circ} \mathrm{C}, \mathrm{t}=65 \mathrm{~min}, \mathrm{R}=$ $2.74 \mathrm{~mm}, \mathrm{~N}_{1}=27 \mathrm{~mm}$

Calculated $\mathrm{SF}=1.68 \mu \mathrm{m}$

In the present study SF results have been observed for three different materials. If further any change in material is there that may be compensated by input parameter that is $\mathrm{PT}$ ' $\theta$ '.

Table 8: Radiography analysis of castings

\begin{tabular}{|c|c|c|c|c|c|}
\hline $\begin{array}{c}\text { S. } \\
\text { No. }\end{array}$ & $\begin{array}{c}\text { Ratio } \\
(\mathrm{V} / \mathrm{A})\end{array}$ & $\begin{array}{c}\mathrm{LC} \\
(\text { Total no. of } \\
\text { layers fixed to } 8)\end{array}$ & $\begin{array}{c}\text { Type of Metal/ } \\
\text { Pouring Temp. }{ }^{\circ} \mathrm{C}\end{array}$ & $\begin{array}{c}\text { Gas Hole } \\
\text { Level }\end{array}$ & $\begin{array}{c}\text { Lhrinkage } \\
\text { Level }\end{array}$ \\
\hline 1 & 2.74 & $1+1+3+3$ & $\mathrm{Al}\left(600^{\circ} \mathrm{C}\right)$ & 3 & -- \\
\hline 2 & 2.74 & $1+1+2+4$ & $\mathrm{~S} . \mathrm{S}\left(1550^{\circ} \mathrm{C}\right)$ & 4 & 3 \\
\hline 3 & 2.74 & $1+1+4+2$ & $\mathrm{M} . \mathrm{S}\left(1600^{\circ} \mathrm{C}\right)$ & - & - \\
\hline 4 & 3.78 & $1+1+3+3$ & $\mathrm{~S} . \mathrm{S}\left(1550^{\circ} \mathrm{C}\right)$ & 2 & 2 \\
\hline 5 & 3.78 & $1+1+2+4$ & $\mathrm{M} . \mathrm{S}\left(1600^{\circ} \mathrm{C}\right)$ & -- & 3 \\
\hline 6 & 3.78 & $1+1+4+2$ & $\mathrm{Al}\left(600^{\circ} \mathrm{C}\right)$ & - & - \\
\hline 7 & 4.09 & $1+1+3+3$ & $\mathrm{M} . \mathrm{S}\left(1600^{\circ} \mathrm{C}\right)$ & 5 & 4 \\
\hline 8 & 4.09 & $1+1+2+4$ & $\mathrm{Al}\left(600^{\circ} \mathrm{C}\right)$ & -- & 4 \\
\hline 9 & 4.09 & $1+1+4+2$ & $\mathrm{~S} . \mathrm{S}\left(1550^{\circ} \mathrm{C}\right)$ & -- & - \\
\hline $10^{*}$ & 2.74 & $1+1+4+2$ & $\mathrm{Al}\left(600^{\circ} \mathrm{C}\right)$ & - & - \\
\hline
\end{tabular}

*Shows optimized SF conditions as per Table 5

\section{ACKNOWLEDGEMENTS}

The authors would like to thank Manufacturing research lab, GNDEC Ludhiana for technical support.

\section{REFERENCES}

1. Yadav, N. and Karunakar, D.B., 2011, "Effect of process parameters on mechanical properties of the investment castings produced by using expandable polystyrene pattern", International Journal of Advances in Engineering \& Technology, Vol. 1(3), pp. 128-137.

2. Yang, J., Shi, Y., Shen, Q., and Yan, C., 2009, "Selective laser sintering of HIPS and investment casting technology", Journals of Material processing Technology, Vol. 209, pp. 191-198.

3. Ibrahim, K. M., Mhaede, M., and Wanger, L., 2011, "Mechanical characterization of cp-Ti produced by investment casting", Transactions of Non- ferrous Metal Society of China, Vol. 21(8), pp. 1735-1740.

4. Jiang, J., and Liu, X.Y., 2007, "Dimensional variations of castings and moulds in the ceramic mould casting process", Journals of Material Processing Technology, Vol. 189(1-3), pp. 247-255.

5. Singh R., and Singh P., 2011, "Effect of slurry layers on the properties of Investment cast components", International journal of materials science and engineering, Vol.2(1-2), pp. 77-79.

6. Wang, S., Miranda A.G., and Shih C., 2010, "A Study of Investment Casting with Plastic Patterns", Materials and Manufacturing Processes, Vol.25, pp. 1482-88.

7. Chattopadhyay, H., 2011. "Estimation of solidification time in investment casting process", The International Journal of Advanced Manufacturing Technology, Vol. 55(1-4), pp. 35-38.

8. Rafique, M.M.A., and Iqbal, J., 2009, "Modeling and simulation of heat transfer phenomena during investment casting", International Journal of Heat and Mass Transfer, Vol. 52(7-8), pp. 2132-2139.

9. Beeley, P.R., and Smart, R.F., 1995, "Investment Casting, 1st ed., The University Press, Cambridge, UK.

10. Mishra, S., and Ranjana, R., 2010, "Reverse Solidification Path Methodology for Dewaxing Ceramic Shells in Investment Casting Process", Materials and Manufacturing Processes, Vol. 25(12), pp. 1385-88.

11. Sidhu, B.S., Kumar, P., and Mishra, B.K., 2008, "Effect of slurry composition on plate weight in ceramic shell investment casting", Journal of Materials Engineering and Performance, Vol. 17,pp. 489-498. 
12. Dong, Y., Bu, K., Dou, Y., and Zhang, D., 2011, "Determination of interfacial heat-transfer coefficient during investment casting process of single-crystal blades", Journal of Materials Processing Technology, Vol. 211(12), pp. 2123-2131.

13. Singh, S., 2012, "Investment casting application: A case study of ball valve spherical disc, M.Tech Thesis, P.T.U. Jalandhar.

14. Konrad, C.H., Brunner, M., Kyrgyzbaev, K., Völkl, R. and Glatzel, U., 2011, "Determination of heat transfer coefficient and ceramic mold material parameters for alloy IN738LC investment casting", Journal of Materials Processing Technology, Vol. 211(2), pp. 181-184.

15. Singh, S., and, Singh, R., 2014, "Taguchi approach for modelling of surface hardness in investment casting", Proceedings of IMechE Part-E (Jol. of Process Mechanical Engineering). In-Press.

16. Singh, R., and Khamba, J.S., 2009, Mathematical modeling of surface roughness in ultrasonic machining of titanium using Buckingham$\Pi$ approach: A Review", International Jol. of Abrasive Technology, Vol. 2(1), pp. 3-24.

17. Singh, R. and Khamba, J.S., 2009, "Mathematical modeling of tool wear rate in ultrasonic machining of titanium", The International Jol. of Advanced Manufacturing Technology, Vol. 43(5-6), pp. 573-580.

18. Singh, R., 2014, "Modeling of surface hardness in hot chamber die casting using Buckingham's $\pi$ approach", Journal of Mechanical Science and Technology, Vol. 28(2), pp. 699-704. 